\title{
Changing Behavioral Patterns in Grocery Shopping in the Initial Phase of the Covid-19 Crisis-A Qualitative Study of News Articles
}

\author{
Niklas Eriksson, Minna Stenius \\ Department of Business Management and Analytics, Arcada University of Applied Sciences, Helsinki, Finland \\ Email: niklas.eriksson@arcada.fi
}

How to cite this paper: Eriksson, N., \& Stenius, M. (2020). Changing Behavioral Patterns in Grocery Shopping in the Initial Phase of the Covid-19 Crisis-A Qualitative Study of News Articles. Open Journal of Business and Management, 8, 1946-1961. https://doi.org/10.4236/ojbm.2020.85119

Received: July 8, 2020

Accepted: August 7, 2020

Published: August 10, 2020

Copyright $\odot 2020$ by author(s) and Scientific Research Publishing Inc. This work is licensed under the Creative Commons Attribution International License (CC BY 4.0).

http://creativecommons.org/licenses/by/4.0/

\begin{abstract}
Covid-19, as both a health and an economic crisis, has substantially affected consumers, businesses, industries, and nations in all parts of the world. In this study the aim was to identify trends in consumers' changing behavioral patterns in grocery shopping in the initial phase of the Covid-19 crisis by conducting a qualitative inductive analysis of news articles on the topic in Finland. Six thematic consumer reactions were identified: 1) Panic-buying, 2) Changes in cooking behavior, 3) Increased sensitivity towards the shopping environment, 4) Switch to online grocery shopping, 5) Increased interest for new services and 6) Careless in-store behavior. The study showed that initially consumers expressed some extreme behaviors, which, however, subsided relatively fast. Importantly, the study gave clear indications that consumers started shifting to online grocery shopping, which may induce more fundamental and enduring changes in grocery retail. Furthermore, the study also suggests that consumers' increased interest in new types of services is probably here to stay, fueling further innovations. Suggestions for further research are also discussed.
\end{abstract}

\section{Keywords}

Covid-19, Consumer Behavior, Crisis, Grocery Shopping, Online Retail

\section{Introduction}

How do consumers react when they are faced with a life-threatening disease such as Covid-19? Some crises have altered consumer behavior towards certain companies, such as Oil companies in disastrous leakages, others have affected consumer behavior towards certain industries, such as the threat of the mad cow 
disease on the meat industry, and different economic crises have affected consumer behaviors compromising the economics of entire nations (Pennings et al., 2002; Duțu, 2020). While Covid-19 is first and foremost a health crisis, it is also a serious economic crisis globally, impacting consumers, companies, industries and nations in all parts of the world. Because of restrictions introduced to prevent the transmission of the deadly virus, new ways to work, interact, and take care of daily chores, such as grocery shopping, have emerged affecting both individual consumers and businesses. The world's merchandize trade is expected to fall by between $13 \%$ and $32 \%$ in 2020 due to the Covid-19 pandemic (World trade organization, 2020), and while the long-term effect of Covid-19 on the retailing sector is yet to be determined, its short-term effect has already been substantial (Roggeveen \& Sethuraman, 2020).

This study will focus on the retail industry, and more specifically on grocery shopping. The retail grocery industry has during the immediate phases of Covid-19 witnessed changes in collective patterns of consumer behavior, even a radical change in demand for certain products, online shopping and home delivery services. To a degree these changes result from restrictions and recommendations from national governments and different local and global authorities to protect especially persons belonging to a Covid-19 risk group, but also from drivers in the minds of the consumers to protect themselves, the ones close to them and people they meet, or are in contact with. Retailers of essential products such as food and healthcare have, due to increased demand and requirements, faced challenges of inventory, logistics management and keeping their stores a safe environment. On the contrary, retailers of non-essential goods, such as apparel and footwear, have faced plummeting sales and a need to develop new ways to hold on to customers, who are working remotely and shopping from their home, just to stay afloat (Roggeveen \& Sethuraman, 2020). In crises retail consumers change their preferences regarding such things as what goods to buy, where to shop and how often (Nie et al., 2010). Consumers are also likely to learn or develop new shopping routines due to a crisis like Covid-19 (Roggeveen \& Sethuraman, 2020). Understanding consumer buying patterns emerging in crises plays an important role for the success of any business organization (Sharma \& Sonwalkar, 2013).

Consumer buying behavior is a collection of decision-processes and subsequent behaviors, planned and unplanned, and determined by internal and external factors (Sharma \& Sonwalkar, 2013). Risk and uncertainty are key components in the decision-process and consumer behavior in a risk-related crisis is driven by different factors for different consumer segments (Pennings et al., 2002). Drivers of consumer behavior in crises are commonly looked at from the perspective of consumers' risk perceptions and risk attitude. Consumers have been segmented into "The panicked consumers", "The prudent consumers", "The concerned consumers" and "The rational consumers" (Amalia \& Ionut, 2009). According to the same authors, in crises, such as an economic crisis, food 
crisis or terrorism related crisis, the panicked consumer tends to overreact and drastically cut spending whereas the prudent consumer carefully plans spending and postpones major purchases. The concerned consumers also plan their spending carefully, remaining loyal to certain brands, but they may be ready to try new and innovative products in spite of the hard times. The rational consumers in turn are not risk averse and their behavior remains essentially unchanged.

Panic as a state of intense fear and high arousal may trigger major changes in consumer behavior (Duțu, 2020). When studying consumer responses to the swine flu (H1N1) threat, fear was highlighted as a key predictor of behavior change (Dedeoglu \& Ventura, 2017), and extreme reactions can obviously put companies in stressful situations (Amalia \& Ionut, 2009). Consumer behavior in crises is, however, not always consistent with the true level of risks (Pennings et al., 2002), and therefore, the initial stages of a crisis may witness extreme behavior, which then gradually turns into more normalized behavior or possibly a "new-normal behavior".

While research should set out to investigate various aspects of the Covid-19 crisis from a short-term, mid-term and long-term perspective (Pejić-Bach, 2020), this study aims to identify trends in consumers' changing behavioral patterns in grocery shopping in the initial phase of the Covid-19 crises.

\section{Method}

For the purpose of this study data was collected in Finland during the first phase of the Covid-19, between March 13 and May 15, 2020. The situation in Finland on March 15, 2020, was 48 confirmed Covid-19 cases and 0 deaths and on May 15, 2020, the confirmed Covid-19 cases were 6.228 and 293 deaths (5.3 deaths out of 100.000 inhabitants) (Finnish Institute for Health and Welfare, 2020). Finland called a state of emergency on March 16, 2020. The numbers (such as confirmed cases, hospitalized persons, deaths) were quite moderate compared to many other European countries, even if Finland was not completely locked-down during this time period. For example, people were allowed to freely move around outdoors and shopping centers remained opened. On the other hand, strong pre-cautions and recommendations were given to avoid close human contact, people over 70 were to avoid visiting grocery stores, working remotely was strongly recommended, schools were closed on March 18, 2020, restaurants were closed on April 3, 2020 (except for take-away services), the borders were also closed and other restrictions and recommendations put into place.

As a data source Finnish news articles reporting on consumer reactions to grocery shopping were collected during the initial phase of the crisis, the underlying logic being that for a reaction to be substantial enough and/or collectively relevant, it must have received some media attention. Search terms such as (translated from Finnish) "Effects of corona on grocery shopping", "Grocery shopping online corona", "Corona grocery shopping", "Corona effects on food 
retailers", "Corona effects on restaurants", "Commerce", "Online commerce", "Grocery store", "Cooking and corona" etc. were used. These terms were used in Google search, on different major Finnish media websites such as Yle.fi, MTVuutiset.fi and Hs.fi, but also on industry websites such as Yrittajat.fi, Kesko.fi, S-ryhma.fi, Kauppa.fi and Pty.fi. Articles for analysis were chosen based on article heading relevance and the initial reading of the articles. The final sample as of May 15, 2020, constituted of 30 articles, see Table 1 for a summary.

A qualitative content analysis was conducted by inductively identifying themes emerging from the article texts. First, the articles were stored and coded in the software QDA Miner Lite. In the coding process we were in the article texts looking for underlying concepts, characteristics and patterns (Miles et al., 2014). All in all, 29 different ideas were identified. These we call $1^{\text {st }}$ order codes, for example, "Storing Up", "Empty Shelf", "More Online" and "Logistics Problems". Then the codes were reassessed by identifying similarities and differences, and similar ones bundled to larger thematic groups ( $2^{\text {nd }}$ order themes). Based on the coded data a first draft of tentative themes emerged. The articles were then re-read and the themes were further complemented and revised. The final six themes are presented in the next chapter, along with quotations from the articles. A summary of the themes is presented in Table 2.

\section{Results}

The results were grouped into six main themes: 1) Panic-buying, 2) Changes in cooking behavior, 3) Increased sensitivity towards the shopping environment, 4) Switch to online grocery shopping, 5) Increased interest for new services and 6) Careless in-store behavior.

Table 1. Sample.

\begin{tabular}{lc}
\hline \multicolumn{1}{c}{ Source of articles } & $\mathrm{N}=30$ \\
\hline News media sites & 6 \\
Yle.fi (The Finnish broadcasting company) & 4 \\
MTVuutiset.fi (A Finnish commercial TV and media channel) & 6 \\
HS.fi (The largest newspaper in Finland) & 4 \\
\multicolumn{1}{c}{ Ondustry sites } & 2 \\
S-ryhmä.fi (A major Finnish retailing cooperative organization) & 3 \\
Kesko.fi (A major Finnish retailing conglomerate) & 3 \\
Yrittajat.fi (An interest and service organization for SMEs) & 1 \\
Pty.fi (Finnish grocery trade association) & 1 \\
Kauppa.fi (Finnish Commerce Federation) &
\end{tabular}


Table 2. Identified themes.

\begin{tabular}{|c|c|}
\hline Theme & Description \\
\hline Panic-buying & $\begin{array}{l}\text { Over demand for long-lasting food or perceived "survival products" } \\
\text { such as toilet paper, canned food, pasta, rice and frozen products. } \\
\text { Also cleaning and hygiene products. Especially in the very initial weeks. } \\
\text { Pictures and views of empty shelfs led to questioning if supply will last, } \\
\text { led possibly to even more panic-buying. }\end{array}$ \\
\hline $\begin{array}{l}\text { Changes in } \\
\text { cooking behavior }\end{array}$ & $\begin{array}{l}\text { School children at home and remote working led to unprecedented } \\
\text { increase in home cooking and baking. Increased sales in total grocery } \\
\text { sales and baking products (like yeast). The one-time purchase quantity } \\
\text { increased as well. Consumers may rely on traditions in crises and thus } \\
\text { some consumers seemed to rediscover old familiar tastes. }\end{array}$ \\
\hline $\begin{array}{l}\text { Increased sensitivity } \\
\text { towards the shopping } \\
\text { environment }\end{array}$ & $\begin{array}{l}\text { The increased sensitivity towards the shopping environment led to } \\
\text { new shopping procedures. Consumers increasingly took care of hand } \\
\text { hygiene, keeping safety margins, conducting systematic and speedy } \\
\text { shopping, visiting during less busy hours, visiting stores alone, } \\
\text { or having someone else do the shopping for you and reducing shopping } \\
\text { frequency. Special opening hours and new phone services with home } \\
\text { delivery for elderly ( } 70+\text { ) became popular. Also, the monetary } \\
\text { value of a contactless payment increased. }\end{array}$ \\
\hline $\begin{array}{l}\text { Switch to online } \\
\text { grocery shopping }\end{array}$ & $\begin{array}{l}\text { Consumers created an enormous increase in online grocery shopping. } \\
\text { Bigger one-time shopping quantities online compared to one-time } \\
\text { purchases in brick and mortar stores. However, retailers struggled } \\
\text { to keep up with the demand and optimizing logistics. } \\
\text { Especially families with children but also risk groups and } \\
50+\text { persons were more active online. }\end{array}$ \\
\hline $\begin{array}{l}\text { Interest for new } \\
\text { service concepts }\end{array}$ & $\begin{array}{l}\text { Initial demand moved from restaurants to supermarkets. } \\
\text { However, creation of new service concepts by both retailers and } \\
\text { restaurants, such as digital services combined with pick up or } \\
\text { home delivery, showed that there was an undiscovered need among } \\
\text { consumers or just niche for new services like different } \\
\text { "food bag concepts". The Covid-19 crisis seems to have revealed this } \\
\text { need opportunity. Also, an increased need for bigger packages } \\
\text { emerged some wholesalers opened up temporarely for consumers. }\end{array}$ \\
\hline $\begin{array}{c}\text { Careless in-store } \\
\text { behavior }\end{array}$ & $\begin{array}{l}\text { No or minor changes in consumers' in-store behavior, } \\
\text { despite instructions on safety procedures.Even perceived by } \\
\text { retail employees as reckless consumer behavior. }\end{array}$ \\
\hline
\end{tabular}

\subsection{Panic-Buying}

In the very beginning of the Covid-19 crisis there were many consumers, who overreacted to the new and uncertain situation by panic-buying goods, to the point of attracting media attention. Goods bought were long-lasting food or perceived "survival products" such as toilet paper, canned food, pasta, rice and frozen products. Also, cleaning and hygiene products were on very high demand. The overwhelming demand of these types of products led to re-filling problems for the stores and pictures in the reviewed articles (see e.g. Yle.fi, March 19, 2020, https://yle.fi/uutiset/3-11265467 and Hs.fi, March 28, 2020, https://www.hs.fi/talous/art-2000006455577.html) witnessed of empty store shelves. 
"YLE News told on Friday, how stores in many places are running out of toilet paper and groceries as people are storing-up." (Yle.fi, March 14, 2020)

"Finns store-up toilet paper and canned food, but now one can see from the shelves that the phenomenon is much larger. The shelves start to become very empty for some product types." (Hs.fi, March 28, 2020)

The empty shelves raised further questions, among consumers and media, of possible food shortage. This again fueled further anxiety and even more consumers seemed to be panic-buying. Retailers, different organizations, authorities and politicians urged consumers to be rational.

"Stop unnecessary panic-buying in the grocery store! List by the Marthas. These foods you really need for home storing." (MTVuutiset.fi, March 13, 2020)

After the first spike the situation seemed to stabilize as evidenced by media showing pictures of re-filled shelves. According to a survey $(\mathrm{N}=502)$ made by the Finnish grocery trade association in April, 92\% were satisfied with the product supply in stores (Pty.fi, April 29, 2020). The concern, thereafter, seemed to turn more towards possible long-term shortages of domestic and import goods, to the degree of self-sufficiency of the nation, and to what would happen if for example farming failed during the summer due to shortage in work force.

"If the corona crisis hits the world's grocery market, could it mean food shortage in Finland? Experts tell how self-sufficient we are regarding beef, grain and root vegetables. Coffee is needed! How about fruits?" (MTVuutiset.fi, April 15, 2020)

"The corona crisis practically hinders all foreign seasonal work force to enter the country. Now the industry is nervous about how more than 16,000 foreign seasonal employees shall be substituted for the incoming harvest season." (Hs.fi, April 1, 2020)

\subsection{Changes in Cooking Behavior}

The closing of schools and strong recommendations to remote working changed cooking behavior in Finnish homes. First, the consumers began to purchase groceries in larger quantities on weekly basis (i.e. growth of the average value of a purchase) to cook for everyone staying at home. Essentially, this meant that all the food consumption at schools (Finnish schools provide one warm meal a day per pupil) and at workplace restaurants was replaced by home cooking.

"Finland s half a million elementary school pupils, in addition to high school students, students at vocational schools, University students and a major part of the office workforce are working remotely. This means, that a big part of the food, that normally is eaten at school or at the workplace restaurant, is now bought from the store and eaten at home... Some of our products sales have grown during the past two weeks by several tens of percent [A manager at a Finnish food producer is commenting]." (Hs.fi, March 28, 2020)

"Customers average spending per purchase has grown during corona, for example, in the $S$-group [Finnish grocery chain]. Amid corona a customer pur- 
chases, typically, a week's food and groceries." (Yle.fi, April 22, 2020)

Second, consumers also started the bake more than normally. Based on an expert opinion in one news article this phenomenon could be explained by people in crises starting to rely on traditions (MTVuutiset.fi, April 8, 2020). Traditions and going back to old ways of doing things may give comfort and a sense of security. Eager baking could also relate to practicalities such as that grocery purchases amid Covid-19 were more in-frequent and products like fresh bread would not last long enough. Baking may also have served as a welcome pastime as people were staying more at home.

"The name of the cooking program on TV 'The whole Finland is cooking' could not be truer. The effect of the corona virus shows an enormous demand for yeast, that amount of dry yeast cannot be found anywhere [An industry manager is commenting]." (Yle.fi, April 28, 2020)

"We believe, that in this time of state of emergency and amid of corona, people will lean against traditions. It also brings a perception of security to rediscover old familiar tastes. [An industry expert is commenting]." (MTVuutiset.fi, April 8, 2020)

\subsection{Increased Sensitivity towards the Shopping Environment}

Consumers renewed their shopping procedures when it came to hand hygiene, safety margins, planned and speedy shopping, visiting during less busy hours, visiting the store without family members, reducing shopping frequency and using contactless payments. This increased sensitivity towards the shopping environment was also strongly urged by authorities and retailers. For examples, gloves of different kind and hand sanitizing were used extensively by consumers, and physical distancing was accomplished by stores' queue marking and plexiglasses to protect cashiers.

"Except for panic-buying the customers of grocery stores have started to use disposable gloves or gym gloves when picking groceries, fruits and vegetables from the shelves." (Yle.fi, March 14, 2020)

"It is not recommendable that the whole family visits the store, it is better that just one person visits. It is advisable that the purchases are well planned in advance, to increase speediness in the shopping. It is sensible to concentrate several days of grocery shopping to one occasion. [Some recommendations from the Finnish food authority.]" (Yhteishyvä.fi, April 7, 2020)

According to a survey $(\mathrm{N}=502)$ by the Finnish grocery trade association, $89 \%$ of store visitors complied with good hand hygiene, physical distancing was managed at most cashiers (67\% responded always and $22 \%$ often) and fairly well in other places of the store (52\% responded always and 35\% often) (Pty.fi, 29 April 2020). Furthermore, a systematic and speedy store visit was managed by a majority (44\% responded always and $37 \%$ often), albeit slightly less so during less busy shopping hours (33\% responded always and $32 \%$ often). Two thirds of the respondents said they visit the store alone and $14 \%$ that someone else do the 
shopping for them. Overall, the respondents were satisfied with the actions taken by the retailers to care for safety and provide guidelines. In another survey $(\mathrm{N}=$ 1000) by the Finnish Commerce Federation $62.5 \%$ of Finns (aged 16 - 79) had decreased their frequency of visits to the grocery store (Kauppa.fi, May 7, 2020).

Also, new services, such as special opening hours for risk groups and phone services with home delivery, became popular among elderly (70+) to reduce risks of exposure to the virus.

“Several K-markets have responded to customers' wishes and provide for risk groups a different time slot for less busy shopping either before opening or within opening hours ... $K$-chain has opened up new information and phone services that help elderly above 70 years old to conduct their grocery shopping." (Kesko.fi, April 3, 2020)

Contactless payment services were also recommended. However, the maximum limit of $50 €$ in Europe, is often too small for grocery shopping, especially when the shopping frequency has decreased and larger quantities are purchased. Nevertheless, the average contactless purchase increased during the initial phase of the Covid-19 crises.

"Contactless payments have been recommended amid corona as a more hygiene mean of payment... The $50 €$ limit used in Finland is the highest possible ... It remains, however, easily too small, as stores are visited less frequently and the purchase quantities are larger at the time of visit. The average purchase with contactless payments has in any case increased by two and a half euro from January to April. [Based on data from the S-bank]" (Hs.fi, April 24, 2020)

\subsection{Switch to Online Grocery Shopping}

Possibly the biggest change, and the most written about phenomenon during the initial stage of Covid-19 in grocery retail was the strong consumer demand for online grocery shopping. Several news articles, analyzed for this study, reported exceptional increases in online grocery sales. For example, Kesko, a Finnish retailing conglomerate, reports an $800 \%$ increase in online grocery shopping amid the corona crisis (Yle.fi, April 28, 2020).

"Kesko's result reveals what Finns are doing in their kitchen amid the corona crisis - online grocery shopping grew as much as $800 \%$. Now online grocery shopping sales account for about five percent of our retail sales ... On what level online grocery shopping is going to be after the crisis is hard to say. [A representative from Kesko is commenting.]" (Yle.fi, April 28, 2020)

This sudden increase in demand surprised many retailers, and especially item-picking and home delivery services became under immense pressure. Online grocery stores were so crowded that customers had a hard time finding a suitable time slot for both self-pick up and home delivery. The delivery times ranged from several days to weeks.

"Online grocery sale has piled during the last week especially in the capital region. The customers may have had to wait for delivery for several days." (Kaup- 
palehti.fi, March 13, 2020)

"S-group has tripled their online grocery sales in April from the year before in April. In many places the delivery slots have been sold out for weeks onward, but it depends regionally. Several hundreds of new employees for picking items in-store for online sales have already started working." (S-ryhma.fi, April 27, 2020)

Also, older consumers (50+) found online shopping convenient and this segment became more active online.

"Corona has stepped up online sales over 50 years old purchase now more actively." (Yrittajat.fi, April 28, 2020)

Likewise, families with children and risk groups started to favor online grocery shopping.

"Especially families with children and risk groups have been favoring online grocery shopping." (Kesko.fi, April 30, 2020)

The older consumers' leap into online shopping was described as exceptionally strong and the longer the crisis goes on, the more permanent this behavior was believed to become.

"Covid-19 has especially worked as some kind of icebreaker for elderly people to start online shopping, it is leaping at the moment. The longer the crisis last, the more permanent this phenomenon will become [comment by the chief economist at Finnish Commerce Federation]." (Kauppa.fi, May 7, 2020)

The amount of groceries purchased online at a time was typically also higher than in the brick and mortar store. The delivery costs were despite the increased online sales kept reasonable, although the price differed between retailers.

"The biggest and most significant difference to brick and mortar stores is that the purchase or the shopping basket size is much bigger. Before corona it was already five times bigger than in brick and mortar stores... Now the difference has grown even bigger ..."(MTVuutiset, May 5, 2020)

"Ordering of food online is not particularly expensive. The price surely differs slightly between stores." (Taloustaito.fi, March 17, 2020)

\subsection{Increased Interest in New Service Concepts}

The restaurant business suffered severely from the Covid-19 crisis. Restaurants were closed on the 3rd of April, but take-away and different home delivery services were still ongoing. Covid-19 basically took the customers away from restaurants and moved them to the grocery stores.

"... orders have decreased since January by even 80 percent in the worst hit restaurant business." (Salkunrakentaja.fi, April 24, 2020)

"Corona raises grocery shopping, but takes away customers from hotels and restaurants." (S-ryhma.fi, March 17, 2020)

To compensate for the plummeting sales, many restaurants quickly shifted gears and began to offer home delivery services, which attracted a great consumer interest. Subsequently, home delivery services grew to such extent that 
restaurant food seemed to become more routine in Finnish homes.

"Wolt and Foodora type of food courier services have grown their orders significantly amid the corona crisis. The extraordinary situation has impacted this, when these services are used and what is ordered from them. One could say that restaurant food has become more ordinary." (Hs.fi, April 24, 2020)

Also, restaurants (even restaurants with Michelin stars) created new concepts, such as ready-made "food bags" for cooking and dining at home. The consumer interest surpassed expectations and consumers hoped for this concept to continue after the Covid-19 crises.

"The demand for food bags has been a relief. There would have been even more demand, but at the moment the physical space and storage are not enough. We have been asked, will we continue with this after the restaurant will re-open [comments from a Michelin star restaurant in Helsinki].” (Yrittajat.fi, April 15, 2020)

Likewise, the ready-made grocery bag concept, with easy lunch and dinner recipes, surged for some online grocery stores. Consumers needed convenient ways to cook as e.g. school children were at home.

"Also, the orders of Sannan Ruokakassi [an online grocer with focus on the food bag concept] grew fiercely directly after the government had an information event regarding social distancing. When schools are closed, lunches and dinners have had to be cooked at home. Many customers, who have ordered their food bag every second week are now ordering every week or several bags for the same week." (Yrittajat.fi, April 28, 2020)

Grocery stores created as well new service concepts to deal with the problems faced in overcrowded picking services. For example, Kauppahalli24.fi (a pure online grocer "Market hall 24") created a pop-up service called Kotikaappi24.fi ("Home storage 24") focusing only on dry foods as these types of foods are more easily picked, which eased the peak in demand. Also, an online grocery focusing on clearance food and short-dated stock, Fiksuruoka.fi, saw a double digit increase in demand. They strongly believed that the consumer behavior has changed forever.

"Kotikaappi24.fi is planned as a popup-service and its lifetime is as long as there is demand... However, after corona we will return to a different world when it comes to online shopping [comment from the marketing director of Kauppahalli24.fi].” (Yrittajat.fi, April 28, 2020)

"Food clearance home delivery grocery Fiksuruoka.fi sales doubled For the warehouse double personnel was hired ... We believe that many who have now ordered will continue after the extraordinary situation has ended." (Yrittajat.fi, April 28, 2020)

Also, some wholesalers opened up their doors, at least temporarily, for consumers as the demand for larger packages grew. Especially those wholesalers, who have focused on delivering to restaurants, saw an opportunity to fill the gap in sales and satisfy the consumer need for quantity. 
"Does the small package sizes annoy you no worries, some of the wholesalers opened up their doors to consumers." (Yle.fi, May 9, 2020)

\subsection{Careless In-Store Consumer Behavior}

Although most consumers seem to have prudently followed the instructions regarding safety distancing and hand hygiene when shopping, there were reports of frustration from both retail employees and other consumers that some consumers neglect the precautions and have not changed their behavior at all.

"Frustrated cashiers tell HS about customers' reckless behavior in stores Some do not care at all ... Over 250 persons in customer service answered the HS survey on how customers behavior has changed. The answers brought up careful safeguarding but also great disregard." (Hs.fi, April 14, 2020)

According to the survey $(\mathrm{N}=502)$ by the Finnish grocery trade association (Pty.fi, April 29, 2020) 6\% perceived that other customers do not at all keep the safety distance at the cashier and $22 \%$ perceived only occasional safety distancing by other customers at the cashier.

\section{Discussion}

This study set out to identify changes in patterns of consumer behavior as regards grocery shopping in the initial phase of the Covid-19 crises. Table 2 summarizes the six identified themes from a qualitative analysis of Finnish news articles on the topic.

The identification of the six thematic reactions demonstrates that in a relatively short period of time, the initial phases of Covid-19, consumers' grocery shopping behaviors changed substantially. Some resulted from external recommendations and restrictions by authorities, but the attitudinal and emotional drivers underlying consumer behaviors should not be underestimated. The initial consumer reactions in the Covid-19 crisis are in line with previous research suggesting that some consumers panic and they tend to overreact, or the reaction is not consistent with the true level of risk (Amalia \& Ionut, 2009; Pennings et al., 2002). These types of extreme reactions can put companies in stressful situations (Amalia \& Ionut, 2009), which was also evident in this study. Pictures of empty store shelfs and retailers struggling to refill led to discussions on possible short-term grocery shortage, which may have fueled even more panic-buying. Media, and today also social media, have a critical role in either fueling or easing the uncertainty in a crisis. Mass media communications regarding health crises can have a powerful effect on peoples' reactions and attitudes according to research (Sato \& Campbell, 2014). This is an aspect that could be more thoroughly looked into regarding the Covid-19 crisis, as major shifts in collective behaviors cause unnecessary stress for businesses, but they may also create new risks in what is already a crisis, such as shortages of protective gear for frontline health care personnel. Moreover, retailers ought to thoroughly review their just-in-time systems and different types of logistics and supply chains to be better prepared 
for sudden increases in demand for certain products and services.

Some consumers seemed to go back to old traditions of cooking and, thus, rediscovering old familiar tastes. This may express an increased need for safety in a crisis situation, or perhaps social isolation created an opportunity to engage in cooking together as a fun pastime. Furthermore, there seemed to be a readiness to try new types of services. This type of behavior fits quite well with the description of the "concerned consumer" (Amalia \& Ionut, 2009). These consumers will take a step back in consumption, but at the same time they are the readiest to try new innovative products. Plausibly the most important development in the initial phase of the crisis was the shift to online grocery shopping, also among the older population. According to the articles studied, industry experts do not see us returning to the pre-covid consumer behavior. In other words, more extensive use of online grocery shopping and new types of service concepts are here to stay. This may pave the way to a much more fundamental shift in how we conduct and perceive grocery shopping.

Online grocery shopping has only just begun, and while innovative, the business in Finland is still in its infancy, lacking many features and untapped opportunities. The retailers who can provide incremental innovative features and a better customer experience are often the winners in a crisis (Nie et al., 2010), and being a first-mover seems particularly important in online grocery business (McKinsey \& Co, 2013). It is possible that those who responded fast when the crisis started, by offering and extending good online services (convenience, assortment, experience; McKinsey \& Co, 2013), have locked in a large group of loyal repeat customers, in line with Singh and Söderlund (2020), whose study suggested that good online experience generates repurchase intentions in grocery shopping. This may prove to be an important group of customers as they presumably concentrate all, or a large part, of their grocery purchases to a single retailer. Such increase in the share of wallet, as a result of going online, was seen in Melis et al. (2016) study of UK clients. We can conclude that while digital service innovation seems to have been particularly important for grocery retailers and restaurants to stay afloat during the initial phases of the Covid-19 phases, we may have only seen the beginning of a much more fundamental change.

How much and how permanently the mindset of the consumer has changed remains to be seen. Prior studies suggest that grocery shopping is a habitual process, not easily changed (Hoyer et al., 2013), and while not yet well understood, this seems to also apply to online grocery shopping (Melis et al., 2016). Hence, the crisis may have pushed consumers to undertake new routines, but the longer the crisis goes on, the more likely it is that they become accustomed to the new ways of shopping, and the more likely the new routines stick. It is, however, not accurate to suggest that one habitual process is replaced by another. It is more reasonable to think of grocery shopping as a group of related behaviors, and while some will always require deliberation, some can become habitual. Habits stick because they are automatic behavioral responses to cues in the 
context, acquired through repetition (Orbell \& Verplanken, 2010), and such responses may trigger other related actions. For instance, if the routine becomes to order groceries on a particular day, other typical things happening on that day are likely to prompt the shopping routine. If again a habit develops to add to the online grocery list during the week, it is possible that the mere presence of a device such as a laptop or tablet on the kitchen counter triggers this action. This may not alone be enough for the more deliberate online ordering to take place, but it may be a critical step in the process. There may be many other such cues, even ones initiated by the retailer, such as a text message reminder, etc. Future studies should investigate, how the new normal behavior actually emerges, and what the role and nature of habit formation vis-à-vis deliberation, and other determinants (e.g. service features offered) in this process are.

Another aspect arising from the study relates to consumers' increased sensitivity towards the shopping environment. This will most likely have to be taken into consideration considerably more by retailers also after the Covid-19 crisis, even if restrictions and recommendations regarding social distancing and hygiene aspects decrease. It should also be noted that there seemed to be a small group of consumers, who did not substantially change their behavior in stores. Their behavior was even perceived as reckless by retail employees. This is in line with previous findings that there is a consumer group that wants to stick to their "usual behavior" (Amalia \& Ionut, 2009). We are so to speak renegotiating the behavioral norms relating to grocery shopping but not everyone agrees. This can put retailers in stressful situations as employees do not feel safe and other consumers may avoid shopping even more. The increased sensitivity towards the shopping environment and perceptions of reckless behavior may indeed require considerations and changes in the setup of future stores and other types of physical touch points.

\section{Conclusion}

This study has primarily contributed to previous research on consumer responses emerging in crises (Amalia \& Ionut, 2009; Dedeoglu \& Ventura, 2017; Duțu, 2020; Kaytaz \& Gul, 2014; Nie et al., 2010; Pennings et al., 2002; Sharma \& Sonwalkar, 2013). The Covid-19 crisis is a relatively new topic, but the crisis has shown profound impact on the retail industry in its initial phase (Roggeveen \& Sethuraman, 2020). This study identified six main themes regarding changes in consumer behavior related to grocery shopping amid the initial phase of the Covid-19 crisis: 1) Panic-buying, 2) Changes in cooking behavior, 3) Increased sensitivity towards the shopping environment, 4) Switch to online grocery shopping, 5) Increased interest for new services and 6) Careless in-store behavior. These, changes were formed on both external stimuli, such as restrictions and recommendations by authorities, and internal stimuli, in the mind of the consumer. The study showed that consumers expressed some extreme behavior in the initial phases of the Covid-19 crisis, which, however, subsided relatively fast. 
Importantly, the study gave clear indications that consumers started shifting to online grocery shopping, which may induce more enduring changes in a major retail sector. Furthermore, the study also suggested that consumers' increased interest in new types of services is probably here to stay. Hence, further studies could be conducted on the adoption and use of online grocery shopping and other digital innovations in retail, both from the consumer as well as from the retailer perspective. Understanding how a major crisis disrupts our present ways of behaving and conducting business continues to be an important area of study. The initial crisis seems to have contributed to both consumer innovativeness and readiness to try out new things, as well as fostered innovativeness among retailers, restaurants and other food providers, creating new services to cope with the new situation. Crises as fuel for radical innovations in retail are a topic that should be discussed and researched more.

This study is limited to analyzing 30 news articles amid the initial stage of the Covid-19 crisis. The identified themes of changes in behavioral patterns could be refined and further developed in future studies by, for example, conducting interview or survey research. Nevertheless, the identified themes illustrate clearly the diversity of consumer responses that the grocery retail industry may need to deal with in a crisis. This study is also limited to a Finnish context. Cultural and national differences in consumer risk perceptions and attitudes have also been identified, all change responses are not equal in all national markets (Pennings et al., 2002; Amalia \& Ionut, 2009). Furthermore, varying levels of restrictions and recommendations by authorities have been issued in different countries hit by Covid-19. Thus, studies in different markets could be made on consumers' changes in patterns regarding retail shopping amid the Covid-19 crisis. Also, comparative studies ought to be of interest. It is highly likely that the world is in for a long-term economic crisis, but the effects may not show clearly yet in the initial phase of the Covid-19 that was under investigation here. An economic crisis can be a shock to the consumer also in the form of unemployment or fall in income, which leads to uncertainty and constraints on consumption (Kaytaz \& Gul, 2012). Indications of economic uncertainty among consumers seem to be growing. A survey conducted on 8266 Finns suggested that one fourth had needed to cut down on spending amid the Covid-19 crisis (Taloussanomat, 2020). Hence, a mid to long-term perspective, with a longitudinal research approach, on changes in consumer behavior in retail both from the perspective of a health and an economic crisis would be interesting.

\section{Conflicts of Interest}

The authors declare no conflicts of interest regarding the publication of this paper.

\section{References}

Amalia, P., \& Ionut, P. (2009). Consumers' Reaction and Organizational Response in Cri- 
sis Context. Annals of the Faculty of Economics, 4, 779-782.

Dedeoglu, A. O., \& Ventura, K. (2017). Consumer Responses to Swine Flu (H1N1) Threat and Fear Arousing Communications: The Case of Turkey. In C. L. Campbell (Ed.), The Customer Is Not Always Right? Marketing Orientations in a Dynamic Business World. Developments in Marketing Science: Proceedings of the Academy of Marketing Science (pp. 249-258). Cham: Springer. https://doi.org/10.1007/978-3-319-50008-9 66

Duțu, A. (2020). Understanding Individuals' Behavior under Uncertainty: Strategy Key Driver in Economic Crisis. In F. Musso, \& E. Drucia (Eds.), Handbook of Research on Retailing Techniques for Optimal Consumer Engagement and Experiences (pp. 57-85). Hershey, PA: IGI Global. https://doi.org/10.4018/978-1-7998-1412-2.ch004

Finnish Institute for Health and Welfare (2020). Situation Update on Corona Virus. https://thl.fi/en/web/infectious-diseases-and-vaccinations/what-s-new/coronavirus-cov id-19-latest-updates/situation-update-on-coronavirus

Hoyer, W. D., MacInnis, D. J., \& Pieters, R. (2013). Consumer Behavior (6th ed.). Boston, MA: South Western Cengage Learning.

Kaytaz, M., \& Gul, M. C. (2014). Consumer Response to Economic Crisis and Lessons for Marketers: The Turkish Experience. Journal of Business Research, 67, 2701-2706.

https://doi.org/10.1016/j.jbusres.2013.03.019

McKinsey \& Company (2013). The Future of Online Grocery in Europe. https://www.mckinsey.com/ /media/McKinsey/Industries/Retail/Our\%20Insights/The $\% 20$ future $\% 20 \mathrm{of} \% 20 \mathrm{online} \% 20$ grocery $\% 20 \mathrm{in} \% 20$ Europe/The future of online groce ry.ashx

Melis, K., Campo, K., Lamey, L., \& Breugelmans, E. (2016). A Bigger Slice of the Multichannel Grocery Pie: When Does Consumers' Online Channel Use Expand Retailers' Share of Wallet? Journal of Retailing, 92, 268-286. https://doi.org/10.1016/j.jretai.2016.05.001

Miles, M. B., Huberman, A. M., \& Saldana, J. (2014). Qualitative Data Analysis: A Methods Sourcebook (3rd ed.). Thousand Oaks, CA: Sage Publications.

Nie, B., Zhao, F., \& Yu, J. (2010). The Impact of the Financial Crisis on Consumer Behaviour and the Implications of Retail Revolution. In Marketing Science Innovations and Economic Development: Proceedings of 2010 Summit International Marketing Science and Management Technology Conference (pp. 487-493). Sydney: Orient Academic Forum.

Orbell, S., \& Verplanken, B. (2010). The Automatic Component of Habit in Health Behavior: Habit as Cue-Contingent Automaticity. Health Psychology, 29, 374. https://doi.org/10.1037/a0019596

Pejić-Bach, M. (2020). Editorial: Electronic Commerce in the Time of Covid-19-Perspectives and Challenges. Journal of Theoretical and Applied Electronic Commerce Research, 16, 1. https://doi.org/10.4067/S0718-18762021000100101

Pennings, J., Wansink, B., \& Meulenberg, M. (2002). Note on Modeling Consumer Reactions to a Crisis: The Case of the Mad Cow Disease. International Journal of Research in Marketing, 19, 91-100. https://doi.org/10.1016/S0167-8116(02)00050-2

Roggeveen, A. L., \& Sethuraman, R. (2020). How the COVID-19 Pandemic May Change the World of Retailing. Journal of Retailing, 96, 169-171.

https://doi.org/10.1016/j.jretai.2020.04.002

Sato, H., \& Campbell, R. G. (2014). Newspaper Reports on BSE around the Time of the Japan-US Trade Conflicts: Content Analysis of Japanese and US Dailies from 2002 to 2006. Advances in Journalism and Communication, 2, 20-34. 
https://doi.org/10.4236/ajc.2014.21003

Sharma, V., \& Sonwalkar, J. (2013). Does Consumer Buying Behavior Change during Economic Crisis? International Journal of Economics \& Business Administration, 1, 33-48. https://doi.org/10.35808/ijeba/9

Singh, R., \& Söderlund, M. (2020). Extending the Experience Construct: An Examination of Online Grocery Shopping. European Journal of Marketing. https://doi.org/10.1108/EJM-06-2019-0536

Taloussanomat (2020). Jättikysely: Joka neljäs joutunut karsimaan menoistaan koronan vuoksi. https://www.is.fi/taloussanomat/oma-raha/art-2000006508050.html

World Trade Organization (2020). Trade Set to Plunge as COVID-19 Pandemic Upends Global Economy. https://www.wto.org/english/news e/pres20 e/pr855 e.htm 